Journal of Agrometeorology 23 (3) : 306-309 (September 2021)

\title{
Assessment of crop water requirement of field pea (Pisum sativum L.) in foothills valley areas of Manipur, North East India \\ LAISHRAM KANTA SINGH ${ }^{*}$, INGUDAM BHUPENCHANDRA ${ }^{2}$ and S. ROMA DEVI ${ }^{3}$

\author{
${ }^{1} I C A R-K V K$ Imphal West, ${ }^{2} I C A R-K V K$ Tamenglong, ${ }^{3} I C A R-K V K$ Churachandpur \\ ICAR Research Complex for NEH Region, Manipur Centre, India \\ *Corresponding Author email: kanta_lai@yahoo.co.in
}

\begin{abstract}
The purpose of this study was to assess the evapotranspiration in field pea (Pisum sativum L.) in foothills valley areas of Manipur using the Hargreaves-Samani equation to predict the plant water demand. The crop coefficient $\left(\mathrm{K}_{\mathrm{c}}\right)$ values ranged between 0.45 and 1.28 during the crop growth stages of field pea for the five crop seasons (2013-18). The average five-year effective rainfall was estimated to be $59.0 \mathrm{~mm}$, with standard deviation $(\mathrm{SD} \pm$ ) ranging between 4.4 to $35.1 \mathrm{~mm}$. The average crop water requirement for field pea was estimated to be $221.0 \mathrm{~mm}$ and the average water demand for different crop growth stages of field pea was estimated to be $20.0 \mathrm{~mm}$ (initial stage), $52.0 \mathrm{~mm}$ (development stage), $100.0 \mathrm{~mm}$ (mid-season) and $49.0 \mathrm{~mm}$ (late season). Thus, the information generated may help in effective management of crop water requirements for sustainable crop production including field pea in the region.
\end{abstract}

Key words: Crop coefficient, reference evapotranspiration, crop evapotranspiration, effective rainfall

The demand for water is growing day by day due to the fast-growing of the human population, agricultural and industrial growth, and per capita availability of water decreases year by year. This imbalance declines the natural resources on the earth thus threaten to all living beings. Water is an essential component of all living beings on the earth. Water being critical component of all living beings; is essential for food security, life support, industrial production, and ecological sustainability as well as sociodevelopment of a country. An additional 5,600 km³/year of consumptive water will be required to meet potential food demands by the year 2050 (Falkenmark 2007). Water consumption in the agricultural sector is about $75 \%$ of the worldwide water utilized (Falkenmark and Rockström, 2004). Nearly one-third of the world's populations are living in different countries, are experiencing moderate to severe water stress (WMO, 1997). With the everincreasing demand for water due to modern in agricultural practices and rapid urbanization it is essential to focus on efficient consumption and management of accessible water resources. Increasing water demand due to increase in crop production is a new challenge for water resources planners and managers. To cope up with the increasing population, agricultural production needs to be increased along with the irrigation application at the proper time (Khare et al., 2007). Climatic conditions, soil and crop cover patterns are the most significant factors for understanding agricultural water requirements. In India, irrigation is the main water consumption, which occupies more than 80 per cent of total water use (MoWR, 1999). The agricultural segment is the major consumer of water resources around the world and increasing population requires more food production, which enhances more pressure on water consumption. Hence, the assessment of crop water demand will provide valuable information to improve agricultural water management practices for sustainable crop production (Pandey et al., 2008; Mehta and Pandey, 2016; Singh et al., 2019).

The North East Region (NER) in India has abundant water resources, which account for about $46 \%$ of the country's total water resources (Saha, 2011). Although high rainfall is occurring in the region, the lack of adequate rainwater management conditions and adequate soil and water conservation measures lead to severe water scarcity, especially in the post-monsoon period. Therefore, efficient water management requires efficient crop production for agricultural development and for improving the rural economy and quality of life. There are many challenges in sustaining agricultural production with the increased scarcity of water resources and increasing costs of production. However, these restrictions, agricultural production needs to 
rise drastically over the next decade to meet the food requirements and particularly those of the developing nations. Hence, producing more crops with less input resources is a difficult assignment to ensure various securities such as foods, economic, and water in this region. Field pea (Pisum sativum L.) is one of the significantly high-value crops grown in Manipur. The performance of field pea production depends largely on good agronomic practices and effective water management. The present study was, therefore, planned and taken up with specific objectives to assess crop coefficient, to estimate reference and crop evapotranspiration, to evaluate effective rainfall and to estimate water requirement in field pea using the Hargreaves-Samani equation for effective water resources management.

\section{MATERIALS AND METHODS}

\section{Description of the study area and datasets used}

The study was conducted in the Imphal West District of Manipur, North East India. The agrometeorological data viz., maximum temperature, minimum temperature, maximum relative humidity, minimum relative humidity, bright sunshine hours, wind speed and also relevant crop data were collected from ICAR Research Complex for NEH Region, Manipur Centre. For the purpose of this study, five crop seasons (2013-18) data were considered and utilized to achieve the above objectives. The agrometeorological observatory is located geographically at $24.45^{\circ} \mathrm{N}$ latitude and $93.54^{\circ}$ E longitude and $774 \mathrm{~m}$ amsl altitude at the experimental farm, ICAR Research Complex of the NEH Region, Manipur Center, Imphal, Lamphelpat. The average annual rainfall in the study area is $1450 \mathrm{~mm}$ in 152 rainy days; the rainy/monsoon season lasts from the beginning of May to October.

\section{Estimation of crop water requirement}

The depth of crop water demand (CWD) for field pea was estimated by multiplying Evapotranspiration ( $\mathrm{ET}_{\mathrm{o}}$ ) and crop coefficient $\left(\mathrm{K}_{\mathrm{c}}\right)$. Then, crop water requirement (CWR) was computed by subtracting effective rainfall from crop water demand (Smith, 1992).

CWD and CWR were computed using following equations:

$$
\begin{aligned}
& \mathrm{CWD}=\mathrm{ET}_{\mathrm{O}} \times \mathrm{K}_{\mathrm{C}} \\
& \mathrm{CWR}=\mathrm{CWD}-\mathrm{P}_{\mathrm{e}}
\end{aligned}
$$

where, CWD = crop water demand $\left(\mathrm{mm}\right.$ day $\left.^{-1}\right)$, $\mathrm{ET}_{\mathrm{o}}=$ reference evapotranspiration $\left(\mathrm{mm} \quad\right.$ day $\left.^{-1}\right), \mathrm{K}_{\mathrm{c}}=$ crop coefficient, CWR $=$ crop water requirement $(\mathrm{mm}$ day $\left.^{-1}\right)$, and $\mathrm{P}_{\mathrm{e}}=$ effective rainfall $\left(\mathrm{mm} \mathrm{day}{ }^{-1}\right)$.

\section{Estimation of reference evapotranspiration}

In the present study, reference evapotranspiration $\left(\mathrm{ET}_{\mathrm{o}}\right.$ ) was computed using Hargreaves-Samani (HS) equation for the period 2013-18. MS-Excel software was used for the calculation of ET . The Hargreaves-Samani (HS) equation (Hargreaves and Samani, 1985) is empirical in nature and described as:

$$
\mathrm{ET}_{0}=0.408 \times 0.0023 \times \mathrm{R}_{a}\left(\mathrm{~T}_{\text {mean }}+17.8\right)(\Delta T)^{0.5}
$$

where, $\mathrm{ET}_{\mathrm{o}}=$ reference evapotranspiration (mm/day), $\quad \mathrm{R}_{\mathrm{a}}=$ extraterrestrial radiation $\left(\mathrm{MJ} \mathrm{m}^{-2}\right.$ day $\left.{ }^{-1}\right), \mathrm{T}_{\text {mean }}=$ mean air temperature $\left({ }^{\circ} \mathrm{C}\right)$ estimated as the average of minimum $\left(\mathrm{T}_{\min }\right)$ and maximum $\left(\mathrm{T}_{\max }\right)$ daily air temperatures, $\Delta \mathrm{T}=$ difference between $\mathrm{T}_{\max }$ and $\mathrm{T}_{\min }\left({ }^{\circ} \mathrm{C}\right)$, $0.0023=$ an empirical constant of the $\mathrm{H}$-S equation and $0.408=$ conversion factor, which converts $\mathrm{MJ} \mathrm{m}^{-2}$ day $^{-1}$ to $\mathrm{mm} /$ day.

\section{Determination of crop coefficient $\left(K_{c}\right)$}

Values of crop coefficient $\left(\mathrm{K}_{\mathrm{c}}\right)$ of field pea were obtained using the guidelines of FAO Irrigation and Drainage Paper No. 56 (Allen et al., 1998) and values of $\mathrm{K}_{\mathrm{c} \text { mid }}$ and $\mathrm{K}_{\mathrm{c} \text { end }}$ were adjusted at the local condition using local meteorological data of wind speed, minimum relative humidity and mean plant height (Allen et al., 1998).

\section{Determination of Kc mid}

$$
\mathrm{K}_{\mathrm{c} \text { mid }}=\mathrm{K}_{\mathrm{c} \text { mid (Tab) }}+\left[0.04\left(\mathrm{u}_{2}-2\right)-0.004\left(\mathrm{RH}_{\min }-45\right)\right]\left(\frac{\mathrm{h}}{3}\right)^{0.3}
$$

\section{Determination of Kc end}

$$
\mathrm{K}_{\mathrm{c} \text { end }}=\mathrm{K}_{\mathrm{c} \text { end }(\mathrm{Tab})}+\left[0.04\left(\mathrm{u}_{2}-2\right)-0.004\left(\mathrm{RH}_{\min }-45\right)\right]\left(\frac{\mathrm{h}}{3}\right)^{0.3}
$$

value for $\mathrm{K}_{\mathrm{c} \text { end }}$ taken from $\mathrm{FAO}$ Irrigation and Drainage Paper No. 56 (Allen et al., 1998), $\mathrm{u}_{2}=$ mean value for daily wind speed at $2 \mathrm{~m}$ height over grass during the late season growth stage $\left[\mathrm{m} \mathrm{s}^{-1}\right]$, for $1 \mathrm{~m} \mathrm{~s}^{-1} \leq \mathrm{u}_{2} \leq 6 \mathrm{~m} \mathrm{~s}^{-1}$, $\mathrm{RH}_{\text {min }}$ $=$ mean value for daily minimum relative humidity during the late season stage [\%], for $20 \% \leq \mathrm{RH}_{\min } \leq 80 \%, \mathrm{~h}=$ mean plant height during the late season stage $[\mathrm{m}]$, for $0.1 \mathrm{~m} \leq \mathrm{h}$ $\leq 10 \mathrm{~m}$.

\section{Estimation of effective rainfall}

The effective rainfall is that part of the total rainfall, which potentially lowers the plants' net quantity of required irrigation water. Effective rainfall $\left(\mathrm{P}_{\mathrm{e}}\right)$ is 
Table 1: The mean, standard deviation (SD) and coefficient of variation (CV) of effective rainfall, ETc, and crop water requirement during 2013-18 period

\begin{tabular}{|c|c|c|c|c|c|c|c|c|c|c|}
\hline \multirow[b]{2}{*}{ Growth Stage } & \multirow{2}{*}{$\begin{array}{l}\text { Growth } \\
\text { duration } \\
\text { (Days) }\end{array}$} & \multicolumn{3}{|c|}{ Effective rainfall } & \multicolumn{3}{|c|}{ Crop water demand/ET ${ }_{c}$} & \multicolumn{3}{|c|}{ Crop water requirement } \\
\hline & & $\begin{array}{l}\text { Mean } \\
(\mathrm{mm})\end{array}$ & $\begin{array}{c}\text { SD } \\
(\mathrm{mm})\end{array}$ & $\begin{array}{l}\text { CV } \\
(\%)\end{array}$ & $\begin{array}{l}\text { Mean } \\
(\mathrm{mm})\end{array}$ & $\begin{array}{c}\text { SD } \\
(\mathrm{mm})\end{array}$ & $\begin{array}{l}\text { CV } \\
(\%)\end{array}$ & $\begin{array}{l}\text { Mean } \\
(\mathrm{mm})\end{array}$ & $\begin{array}{c}\mathrm{SD} \\
(\mathrm{mm})\end{array}$ & $\begin{array}{l}\text { CV } \\
(\%)\end{array}$ \\
\hline Initial stage & 20 & 14.0 & 17.3 & 121.8 & 30.0 & 2.8 & 9.3 & 20.0 & 12.3 & 62.9 \\
\hline Development stage & 30 & 21.0 & 35.1 & 167.2 & 69.0 & 5.8 & 8.4 & 52.0 & 31.2 & 59.8 \\
\hline Mid-season stage & 35 & 15.0 & 12.8 & 87.7 & 115.0 & 4.1 & 3.5 & 100.0 & 16.1 & 16.1 \\
\hline Late season stage & 15 & 9.0 & 4.4 & 48.4 & 58.0 & 2.1 & 3.6 & 49.0 & 6.2 & 12.8 \\
\hline Total & 100 & 59.0 & --- & --- & 272.0 & --- & --- & 221.0 & --- & --- \\
\hline
\end{tabular}

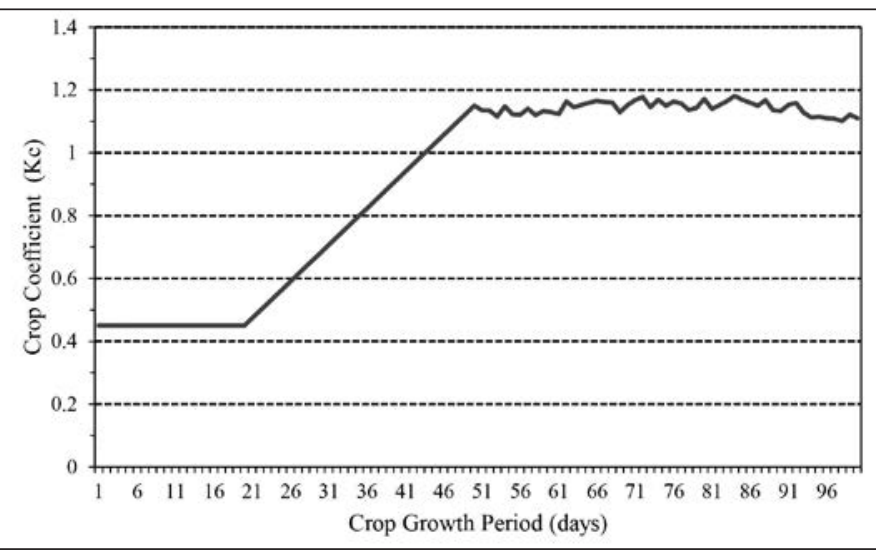

Fig. 1: Mean crop coefficient $\left(\mathrm{K}_{\mathrm{c}}\right)$ of field pea for crop growth period during 2013-18.

simply the amount of rainfall that is valuable for plant growth. Effective rainfall was computed according to the method developed by the USDA Soil Conservation Service (Dastane, 1974), described as:

$P_{e}=P(125-0.2 P) / 125$ for $\mathrm{P} \leq 250 \mathrm{~mm}$

$P_{e}=125+0.1 P \quad$ for $\mathrm{P}>250 \mathrm{~mm}$

where, $P_{e}$ is the effective rainfall (mm/month);

$P$ the total precipitation ( $\mathrm{mm} / \mathrm{month}$ ).

\section{RESULTS AND DISCUSSION}

\section{Variation of crop coefficient}

The variation of mean crop coefficient $\left(\mathrm{K}_{\mathrm{c}}\right)$ of field pea for crop growth period of different years during 2013-18 period has been given in Fig. 1. During the crop development stage of field pea, minimum and maximum value of crop coefficient $\left(\mathrm{K}_{\mathrm{c}}\right)$ was obtained as 0.47 and 1.15 , respectively during all the five seasons of 2013-18 period owing the vibrant and luxurious leaves with higher rate of photosynthesis and transpiration. The standard deviation (SD) during mid-season stage of field pea varied from 0.02 to 0.06 , whereas SD during late season stage for field pea varied from 0.02 to 0.07 .

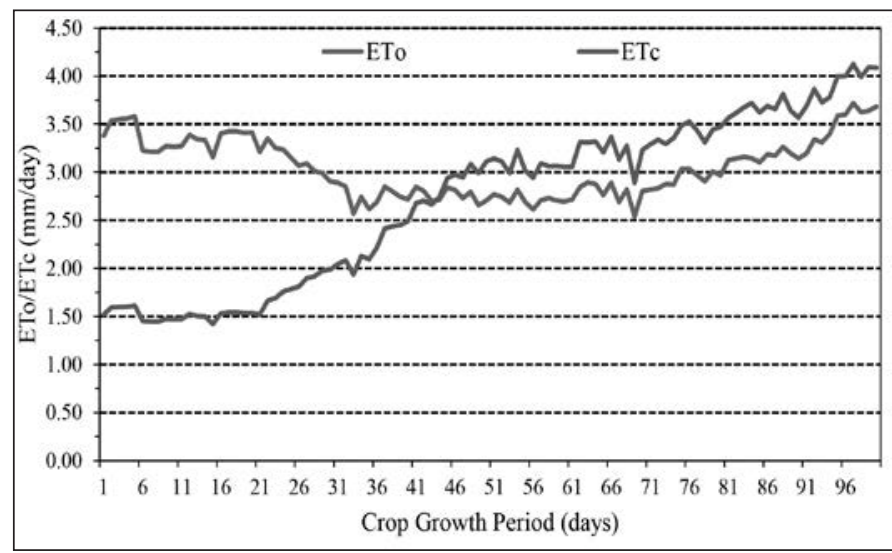

Fig. 2: Comparison between mean $\mathrm{ET}_{\mathrm{o}}$ and $\mathrm{ET}_{\mathrm{c}}$ of field pea for crop growth period during 2013-18.

\section{Reference evapotranspiration (ET) and crop evapotranspiration (ET)}

The comparison between mean $\mathrm{ET}_{\mathrm{o}}$ and $\mathrm{ET}_{\mathrm{c}}$ of field pea for crop growth period of five years 2013-18 period has been given in Fig. 2. The standard deviation (SD) of daily reference evapotranspiration during the growth period of crop varied between 0.04 to 0.85 $\mathrm{mm}$ day $^{-1}$. The standard deviation (SD) of daily crop evapotranspiration during the growth period of field pea varied between 0.05 to $0.89 \mathrm{~mm}^{-1 a y^{-1}}$ because of change in leaf area covering the soil surface beneath over the growing period.

\section{Effective rainfall and crop water requirement}

The variations in mean effective rainfall for different crop growth stages for the period 2013-18 has been given in Table 1 . The average five seasons effective rainfall was estimated as $59.0 \mathrm{~mm}$ with standard deviation (SD) varying between from 4.4 to $35.1 \mathrm{~mm}$. The average crop water demand for field pea crop evaluated was 272.0 $\mathrm{mm} / \mathrm{season}$ and average crop water demand at various crop growth stages estimated were $30.0 \mathrm{~mm}$ (at initial stage), $69.0 \mathrm{~mm}$ (at crop development stage), $115.0 \mathrm{~mm}$ 
(at mid-season stage) and $58.0 \mathrm{~mm}$ (at late season stage). The SD for various crop growth stages varied between 30 to $115 \mathrm{~mm}$ and the coefficient of variation (CV) varied between 3.5 to 9.3 per cent.

The variations in mean crop water requirement of field pea for different crop growth stages during the period 2013-18 has been given in Table 1 . The average crop water requirement for field pea was assessed to be $221.0 \mathrm{~mm}$ and further at different growth stages, the average crop water requirement has been estimated 20.0 $\mathrm{mm}$ (at initial stage), $52.0 \mathrm{~mm}$ (at crop development stage), $100.0 \mathrm{~mm}$ (at mid-season stage) and $49.0 \mathrm{~mm}$ (at late season stage). The SD of crop water requirement at different crop growth stages varied between 6.2 to 31.2 $\mathrm{mm}$ and the coefficient of variation (CV) varied between 12.8 to 62.9 per cent.

\section{CONCLUSION}

It has been concluded with the results obtained using the Hargreaves-Samani equation/method for average crop water requirement in field pea was maximum at peak growth stage than the initial and later stages of crop growth. Therefore, the method can be suitably used to estimate the water demand of field pea at various growth stages and may further assist in effective management of crop water requirements and adaptive strategies for sustainable crop production.

Conflict of Interest Statement : The author(s)declare(s) that there is no conflict of interest.

Disclaimer : The contents, opinions, and views expressed in the research article published in the Journal of Agrometeorology are the views of the authors and do not necessarily reflect the views of the organizations they belong to.

Publisher's Note : The periodical remains neutral with regard to jurisdictional claims in published maps and institutional affiliations.

\section{REFERENCES}

Allen, R.G., Pereira, L.S., Raes, D. and Smith, M. (1998). Crop Evapotranspiration Guidelines for Computing Crop Water Requirements. FAO Irrigation and Drainage Paper No. 56, Food \& Agriculture Organization of the United Nations, Rome, Italy.

Dastane, N.G. (1974). Effective Rainfall. FAO Irrigation and Drainage Paper 25, Food and Agriculture Organization (FAO) of the United Nations, Rome, Italy.
Falkenmark, M. (2007). Shift in thinking to address the 21st century hunger gap moving focus from blue to green water management. Water Res. Manag., 21: 3-18.

Falkenmark, M. and Rockström, J. (2004). Balancing Water for Humans and Nature: The New Approach in Ecohydrology. Earthscan, London, UK.

Hargreaves, G.H. and Samani, Z.A. (1985). Reference crop evapotranspiration from temperature. App. Engg. Agric., 1(2): 96-99.

Khare, D., Jat, M.K. and Sunder, J.D. (2007). Assessment of water resources allocation options: Conjunctive use planning in a link canal command. Res., Conser. Recycl., 51: 487-506.

Mehta, R. and Pandey, V. (2016). Crop water requirement (ETc) of different crops of middle Gujarat. $J$. Agrometeorol., 18 (1): 83-87.

MOWR (1999). Integrated water resource development-a plan for action. Report of the National Commission for Integrated Water Resources Development Plan, Ministry of Water Resources, Govt of India, New Delhi.

Pandey, V., Patel, V.J., Vadodaria, R.P., Patel, H.R. and Shekh, A. M. (2008). Irrigation water requirement and production potentials of major crops over Narmada canal command area in Gujarat. J. Agrometeorol., 10 (Spl Issue-II): 314-320.

Saha, R. (2011). Prediction of water requirement of garden pea (Pisum sativum) under hilly agroecosystem of Meghalaya. Ind. J. Agri. Sci., 81(7): 633-636.

Singh, L.K., Jha, M.K., Chowdary, V.M. and Sannigrahi, S. (2019). Evaluation of crop water demand for sustainable crop production using geospatial tools in a canal command of West Bengal. $J$. Agrometeorol., 21(4): 427-433.

Smith, M. (1992). CROPWAT: A Computer Program for Irrigation Planning and Management. FAO Irrigation and Drainage Paper 46, Food and Agriculture Organization of the United Nations, Rome, Italy.

WMO (1997). Comprehensive Assessment of the Freshwater Resources of the World, Stockholm Environment Institute, Stockholm, Sweden. 